\title{
Variation in the decay resistance and its relationship with other wood characteristics in old Scots pines
}

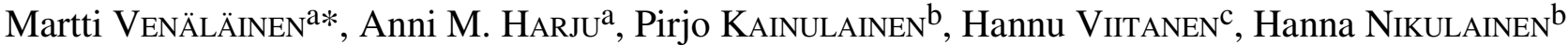 \\ a Punkaharju Research Station, Finnish Forest Research Institute, 58450 Punkaharju, Finland \\ ${ }^{\mathrm{b}}$ Department of Ecology and Environmental Science, University of Kuopio, PO Box 1627, 70211 Kuopio, Finland \\ ${ }^{c}$ VTT Building and Transport, PO Box 1806, 02044 VTT, Finland
}

(Received 23 May 2002; accepted 30 September 2002)

\begin{abstract}
The importance of factors contributing to the natural decay resistance of Scots pine wood was studied. The decay rate of sapwood and outer and inner heartwood of $16 \mathrm{ca}$. 170 -year-old Scots pines was first measured. A six-week decay test was performed with $5 \times 15 \times 30 \mathrm{~mm}$ wood blocks in dishes containing a brown-rot fungus (Coniophora puteana). The average mass loss in sapwood was $141 \mathrm{mg} / \mathrm{cm}^{3}$, in outer heartwood 57 and in inner heartwood 108. The variation between trees was largest in outer heartwood. The corresponding basic densities were 439,456 and $411 \mathrm{mg} / \mathrm{cm}^{3}$. The mass loss was then compared with chemical characteristics and the sorption of water by parallel sample blocks in order to determine which factor has the greatest effect on decay resistance. The differences in heartwood mass loss were explained best by the concentration of pinosylvin and its monomethyl ether, which are phenolics belonging to the group of stilbenes, as well as by the concentration of total phenolics determined by the Folin-Ciocalteu method.
\end{abstract}

decay resistance / heartwood / phenolic compound / pinosylvin / resin acid / moisture content

Résumé - Variation de la résistance à la pourriture et relation avec les autres caractéristiques du bois dans les vieux pins sylvestres. L'étude a porté sur l'importance relative des facteurs à l'origine de la résistance naturelle à la pourriture du pin sylvestre (Pinus sylvestris). Pour commencer, la vitesse de pourriture a été mesurée dans l'aubier et les parties externes et internes du duramen de 16 pins d'environ 170 ans. Un test de pourriture de six semaines a été effectué sur des blocs de $5 \times 15 \times 30 \mathrm{~mm}$ dans des boîtes de Petri, dans lesquelles le champignon lignivore de la pourriture brune (Coniophora puteana) se développait sur une base d'extrait de malt gélosé. Les pertes de poids de l'aubier, de la partie externe du duramen et de la partie interne du duramen ont été de 141,57 et $108 \mathrm{mg} / \mathrm{cm}^{3}$, respectivement. La variation entre les arbres était la plus grande dans la partie superficielle du duramen. Les densités du bois correspondantes étaient de $439,456 \mathrm{et} 411 \mathrm{mg} / \mathrm{cm}^{3}$. Ensuite, les pertes de poids, les caractéristiques chimiques des blocs adjacents et la quantité d'eau absorbée par ces derniers ont été comparées, dans le but de déterminer les facteurs affectant le plus la résistance à la pourriture du bois. Ce sont la teneur en composés phénoliques, en pinosylvine et éther mono-méthylique de cette dernière, faisant partie du groupe des stilbènes, et la teneur en phénols totale déterminée par le réactif de Folin-Ciocalteu qui expliquent le mieux les différences de pertes de poids du duramen. Les différences s'expliquent aussi dans une certaine mesure par le taux d'humidité du bois atteint dans une humidité élevée (HR de $100 \%$ ). Une corrélation significative existait entre la quantité de stilbènes et la quantité d'eau absorbée par le bois immergé dans l'eau.

résistance à la pourriture / duramen / composés phénoliques / pinosylvine / acides résiniques / taux d'humidité

\section{INTRODUCTION}

Several factors have been postulated to contribute to the variation in the natural durability of wood in different tree species. The same factors may also partly cause the variation between different stem sections and between individuals within durable tree species. These factors are mainly associated with the wood extractives that inhibit the primary metabolism or degradation processes of the fungi, or with the permeability of the wood for water, air and fungal hyphae [23].
Approximately the same factors are involved in the formation of heartwood. The difference in the durability of the sapwood and heartwood in several species is the clearest evidence of within-stem variation, and this difference well demonstrates the potential of natural wood-preservation mechanisms.

The interaction between a rot fungus and construction timber is an attempt by a living organism to colonise dead organic tissue that possesses only passive defence mechanisms. In passive defence the question is whether the wood serves as a suitable living environment for the fungus or not (e.g. [21]). There is no

\footnotetext{
* Corresponding author: martti.venalainen@metla.fi
} 
danger of decay as long as the moisture content of the wood remains clearly below the fibre saturation point because easily available water is necessary for several of the metabolic functions of the fungus. If the moisture content remains high for extended periods, then the risk of fungus invasion is high. If desiccation does not take place after colonisation, only the constitutional substances of the wood can interfere with the enzymatic or oxidative reactions caused by the fungus and thus decrease the rate of decomposition.

Scots pine (Pinus sylvestris) timber is a widely used softwood in buildings in the Nordic countries. The most common fungus species causing decay damage to buildings in Finland are Serpula lacrymans, Poria/Antrodia sp. and Coniophora puteana, all of which cause brown-rot [20]. Untreated Scots pine heartwood is classified as moderately to slightly resistant against decay, while the sapwood is classified as perishable [6]. Several studies have recently dealt with the resistance of the juvenile heartwood of relatively young Scots pines. They have demonstrated the genetic variation in decay resistance $[11,13]$, genetic variation and differences in wood characteristics responsible for the resistance $[4,7,8,12,26]$, as well as the genotypic correlations between these characteristics [5].

This study is a part of a larger project evaluating the possibilities to increase the amount and quality of Scots pine heartwood through tree breeding. The main aim of this study was to investigate the relationships between the decay resistance and chemical and hydrophobic properties of the wood, and thus quantify the importance of the individual factors contributing to the natural durability of Scots pine wood. The variation in the in vitro decay rate, and in the extractive content and sorption of water by the sapwood and inner and outer heartwood of mature Scots pine stems were determined.

\section{MATERIAL}

Twenty Scots pine trees were felled in Kuikonniemi stand $\left(61^{\circ} 47^{\prime} \mathrm{N}\right.$, $\left.29^{\circ} 21^{\prime} E^{\prime}\right)$ in the Punkaharju Nature Conservation Area, Finland, in February 1999. The trees were $20-30 \mathrm{~m}$ high, co-dominant or dominant trees in a naturally regenerated, pure Scots pine stand. The age of the trees calculated at stump height was 150-190 years, with an average age of 172 years. The trunks were cut into commercial-sized logs, and a $100 \mathrm{~mm}$ sample disk was taken from the top of the first and second log. In cases were the wood in the stump appeared to be sound, the target length of the first $\log$ was $5 \mathrm{~m}$. As the target length of the second $\log$ was also $5 \mathrm{~m}$, the height of the second sampling point was about $10 \mathrm{~m}$ (Fig. 1). In cases were the visual assessment of the stump section surface indicated that the trunk was suffering from rot damage (six trees), the first log was cut to a length of $3 \mathrm{~m}$ and the length of the second log varied from 3 to $5 \mathrm{~m}$ depending on the soundness of the upper stem. The average number of annual rings in the lower disk was 149 and 131 in the upper one.

The boundary between the sapwood and the heartwood was marked on the disk immediately after cutting according to the clearly visual moisture difference. The average heartwood area of the stump section surface was $51 \%$. The disks were stored in plastic bags at a temperature of $-5^{\circ} \mathrm{C}$. In November 2000 the disks were cut into pieces as shown in Figure 1. The sampling procedure gave four parallel $5 \times 15 \times 30 \mathrm{~mm}$ (tangential, radial, and longitudinal dimension) sized blocks from six points on each of the 40 disks. The total number of sampling points was 240 . The volume of each block was $2.25 \mathrm{~cm}^{3}$ The blocks were stored in plastic boxes at a temperature of $-5^{\circ} \mathrm{C}$.

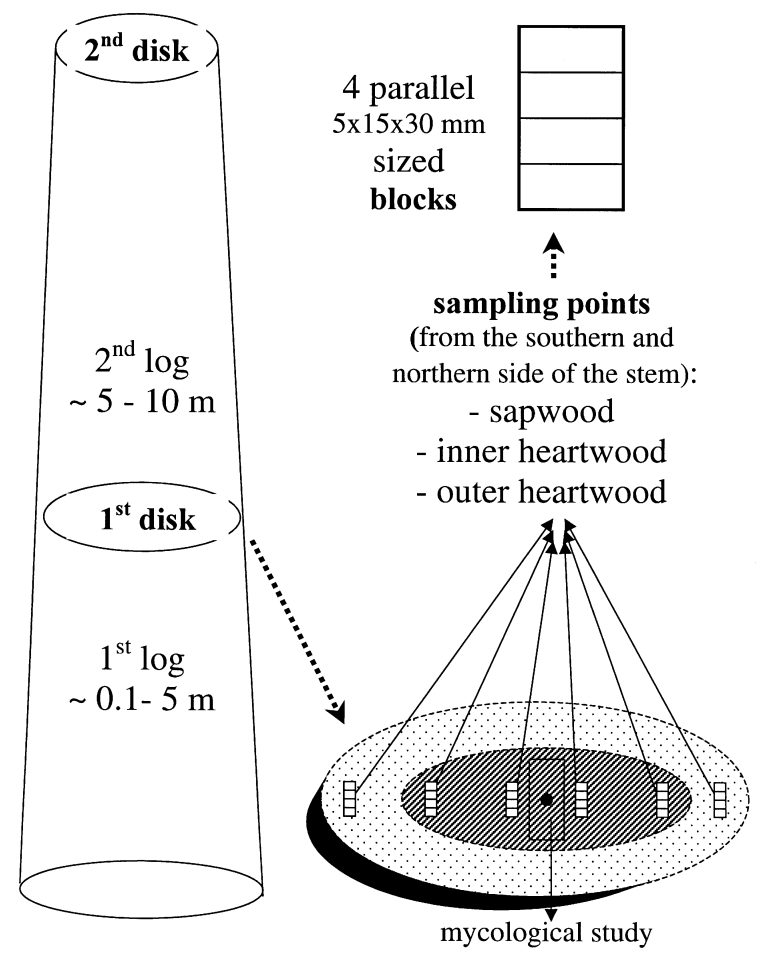

Figure 1. The sampling procedure showing the location of the disks and blocks in the individual trunks.

One additional piece of wood was taken from the centre of each lower disk for mycological studies. Four of the six suspect trees appeared to have heartwood infected by Phellinus pini at a height of $3 \mathrm{~m}$. All the other 16 trees were found to be free of rot fungi.

One of the four parallel wood blocks was subjected to an in vitro decay test. Another block was used for determining the water sorption capacity. The remaining two blocks were milled to powder for the chemical analyses. The wood powder was stored in sealed ampoules at a temperature of $-20^{\circ} \mathrm{C}$. However, in order to reduce costs the chemical analyses were carried out only on samples from the 120 sampling points on the northern side of the stems.

\section{METHODS}

\subsection{In vitro decay test}

The decay rate was determined at VTT Building and Transport using a malt agar plate test, which is a modification of the standardised EN 113 decay test $[25,27]$. Three wood blocks per Petri dish were exposed to a pure culture of a brown rot fungus $(C$. puteana) for 6 weeks. The mass loss of the samples during the incubation, expressed per fresh volume of wood, was used as the measure of the decay rate and thus as an inverse measure of the decay resistance of the wood.

\subsection{Determining the water sorption capacity}

Water bound to hygroscopic cell wall constituents and into voids of wood of radius less than $1.5 \mu \mathrm{m}$ is called $a d$ sorbed water. This critical point of sorption is called the fibre saturation point. It represents a water potential of $-0.1 \mathrm{MPa}$ and, in theory, a relative humidity of 
99.93\% [10]. The water present in the cell lumens and intercellular space is called free or $a b$ sorbed water [29]. Adsorption was determined in a tightly closed steel tank that was half-filled with tap water $\left(+25^{\circ} \mathrm{C}\right)$. The wood blocks (dried at $60^{\circ} \mathrm{C}$ for 48 hours) were placed on steel racks immediately above the water surface. The relative humidity of the tank atmosphere varied between 98 and $100 \%$ in the beginning of the experiment, but stabilised to $100 \%$ within about 50 hours (humidity sensor, Davis Instruments). The mass of the blocks was measured at increasing intervals 4, 8, 14, 24, 34, 48, 72, $96,168,240$ and 336 hours after the start of the test to an accuracy of $1 \mathrm{mg}$. After the last measurement the blocks were dried at $103^{\circ} \mathrm{C}$ for 24 hours, and the dry mass measured. The results were presented as the ratio between the mass of adsorbed water and the mass of the dry wood. This ratio was called the moisture content. In the wetting experiment the same blocks were immersed in water. The mass of the wet blocks was measured 1, 4, 9, 25, 49, 97 and 169 hours after the start of the test, after which the blocks were dried at $103{ }^{\circ} \mathrm{C}$ for 48 hours. The results were expressed as the gross mass of water (i.e. adsorbed and absorbed) per fresh volume of wood. This variable was called the quantity of water after wetting.

\subsection{Chemical analyses}

Resin acids were extracted from the wood powder with petroleum ether-diethyl ether following the procedures of Gref and Ericsson [9]. The extracts were analysed by gas chromatography-mass spectrometry (Hewlett Packard GC type 6890, MSD 5973) using a 30 meter-long, HP-5MS (0.25 mm ID, $0.25 \mu \mathrm{m}$ film thickness, Hewlett Packard) capillary column as described earlier by Manninen et al. [18]. For quantification of the individual resin acids, calibrations were made using known amounts of pure resin acids, and the response factors were determined for each substance relative to known amounts of the internal standard (heptadecanoic acid).

For the analysis of the total concentration of all phenolic compounds wood powder was extracted with $80 \%(\mathrm{v} / \mathrm{v})$ acetone for $30 \mathrm{~min}$. The phenolics were determined by the Folin-Ciocalteu technique using tannic acid as standard [16, 24].

For the quantification of individual stilbenes, i.e. pinosylvin (PS) and pinosylvin monomethyl ether (PSM), wood powder was extracted with $80 \%(\mathrm{v} / \mathrm{v})$ methanol. The extraction was carried out in tubes with vortex mixing at room temperature for $30 \mathrm{~min}$. Vanillin was used as internal standard. The samples were centrifuged and the residue washed two times with $80 \%$ methanol. The supernatants were combined and analysed by HPLC (Hewlett Packard series 1050, $1040 \mathrm{M}$ Series II detection system) using a reversed phase capillary column (HP LiChrospher $100 \mathrm{RP}-18,5 \mu \mathrm{m}, 250 \times 4 \mathrm{~mm}$ ). Analysis was performed by gradient elution with $1 \% \mathrm{v} / \mathrm{v}$ acetic acid solution in water and methanol/acetonitrile/acetic acid (49.5:49.5:1 v/v/v) as described by Lieutier et al. [17]. The flow rate was $1 \mathrm{~mL} \mathrm{~min}^{-1}$ and detection wavelength $308 \mathrm{~nm}$. Peak areas were used to quantify the individual substances, and the results (mg/g dry wt) were calculated relative to known amounts of internal standard. The final results of all the chemical analyses were presented as concentration per fresh volume of wood.

\subsection{Statistical analysis}

One-way ANOVA using tree-wise means was applied to test whether the sapwood and the outer and the inner heartwood differed from each other in the studied wood characteristics. The pair-wise comparisons between the stem sections were performed by Tukey's test. Tree-wise means were used in order to smooth out the random variation between single observations. A simple regression model (response variable $=\beta_{0}+\beta_{1}$ independent variable $+\varepsilon$ ) was applied to study whether the mass loss was dependant on the chemical or phys- ical wood characteristics. The relationships between the independent characteristics were studied with correlation analysis.

The 16 sound trees were included in the statistical analysis. The distributions of the characteristics were first analysed, and 10 out of 96 full records (i.e. records containing decay test and chemical data) were excluded from the main results because of outliers. Four sapwood records were excluded because of a relatively high concentration of stilbenes $\left(2.7 \mathrm{mg} / \mathrm{cm}^{3}\right.$ on average). Six heartwood records were excluded because of very high concentration of resin acids $(65 \mathrm{mg} /$ $\mathrm{cm}^{3}$ on average).

\section{RESULTS}

The radial variations in basic density, mass loss, quantity of water after wetting and concentration of extractives were significant (Tab. I). The difference between the basic density of the outer and inner heartwood reflected the differences in growth rate and in the properties of juvenile and mature wood. The difference between the basic density of the sapwood and outer heartwood was of the same magnitude as the difference in the mass of the extractives. The decay resistance was clearly best in the outer heartwood. However, according to the coefficient of variation $(\mathrm{CV} \%)$, the variation among the trees was also clearly the highest in the outer heartwood. The decay resistance of the inner heartwood was approximately halfway between that of the outer heartwood and sapwood. The concentration of extractives clearly differed between the sapwood and heartwood; stilbenes were almost completely absent in the sapwood. The concentration of stilbenes and total phenolics in the outer and inner heartwood also differed significantly. The variation in the concentration of resin acids was still high among the trees even though the outliers were omitted.

The difference between the quantity of water after wetting in the sapwood and the heartwood was significant. The respective difference in the moisture content at the end of the adsorption test was nearly significant. The variation in both of these characteristics among the trees was low. The adsorption and absorption curves are presented as a function of time in Figure 2.

The regression model was fitted to the data of tree-wise means separately for the sapwood and for the outer and the inner heartwood (Tabs. IIa-IIc). In the case of the sapwood, the regression analyses were not carried out with the PS or PSM data because of the very low concentrations. According to the $\mathrm{R}^{2}$ values, which show the proportion of variation explained by the fitted model (Tab. IIa), the variation in the sapwood mass loss was not explained considerably by any of the independent variables. The best fit was obtained with the concentration of resin acids. However, the positive regression coefficient, which suggests that the higher the concentration the greater is the mass loss, was not significant. The next best fit was obtained with the quantity of water after wetting, but the negative regression coefficient was not significant.

In spite of the large variation in the mass loss of the outer heartwood, the $\mathrm{R}^{2}$ values were fairly low for each of the independent variables. Basic density gave the highest $\mathrm{R}^{2}$ but, when one tree with extremely heavy wood was removed from the data, the $\mathrm{R}^{2}$ value was no more than 0.09 . The concentration of PSM and total phenolics, measured by the Folin-Ciocalteu method, gave approximately the same $\mathrm{R}^{2}$ value. The negative effect of PSM on the mass loss was significant at the 0.05 risk 
Table I. The mass loss and chemical and physical wood characteristics of the 16 mature Scots pines. Each tree was represented by $1-4$ samples in each radial section depending on the characteristic and the number of excluded outlying observations. Tree-wise means were used to calculate the overall means and standard deviations (sd) for the sapwood and the outer and the inner heartwood. The coefficients of variation (CV\%) were used to describe the variation among the trees. One-way ANOVA was applied to test whether the radial sections differed significantly from each other. The pair-wise comparisons were performed by Tukey's test $(-=$ significant difference; , = non-significant difference; $\mathrm{s}=$ sapwood; $\mathrm{o}=$ outer heartwood; $\mathrm{i}=$ inner heartwood). PS = pinosylvin, PSM = pinosylvin monomethyl ether, TAE = tannic acid equivalent.

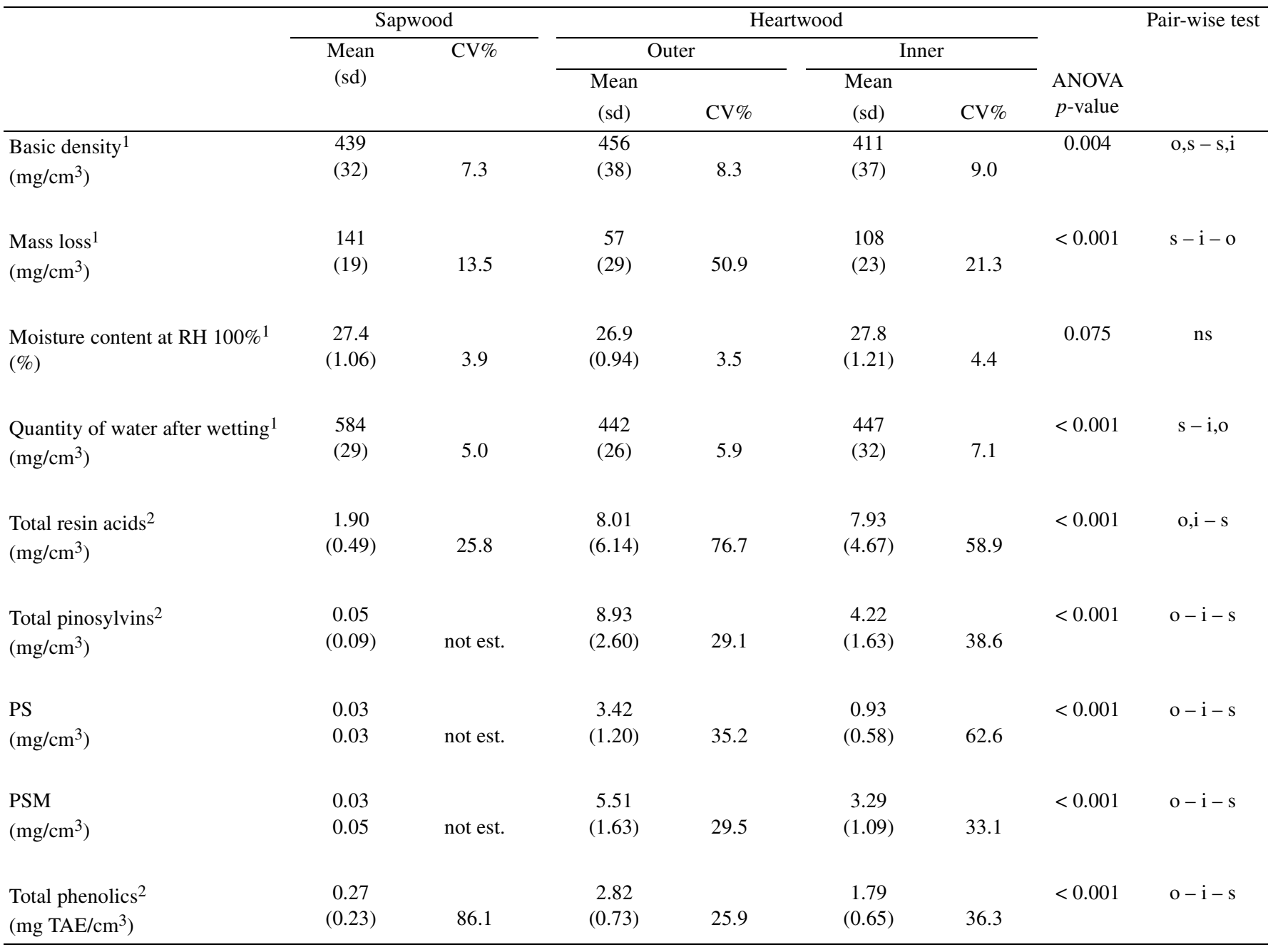

1 (3-)4 samples per tree; ${ }^{2}(1-) 2$ samples per tree.

level, and the effect of total phenolics was nearly significant. The negative effect of PS on the mass loss was less significant although the PS concentration was relatively high. The moisture content and the quantity of water after wetting seemed to have a positive and nearly significant effect on the mass loss. The concentration of resin acids did not explain any of the variation in the mass loss.

In the inner heartwood, the stilbenes PS and PSM well explained the mass loss variation. PS especially had a very significant effect on the decay resistance, even though the concentration of PS was markedly lower than that in the outer heartwood. Also the concentration of total phenolics explained relatively well the variation in mass loss, while the effect of the resin acids was only indicative. Moisture content had a significant positive effect on the mass loss. However, when one tree with extremely hygroscopic wood was removed from the data, the $\mathrm{R}^{2}$ value was 0.27 and the $p$ value for the $t$ test 0.045 . The quantity of water after wetting also had an indicative effect on the mass loss.

The Pearsons' correlation coefficients between the characteristics used as independent variables in the regression analysis are presented in Table III. In the sapwood there was no significant correlation between the independent variables. In the outer heartwood, on the other hand, there was significant positive correlation between the concentration of total phenolics determined by the Folin-Ciocalteu method and the concentration of stilbenes, while the correlation between the concentration of total phenolics and the concentration of resin acids was weak. The quantity of water after wetting and the concentrations of stilbenes and total phenolics were significantly negatively 


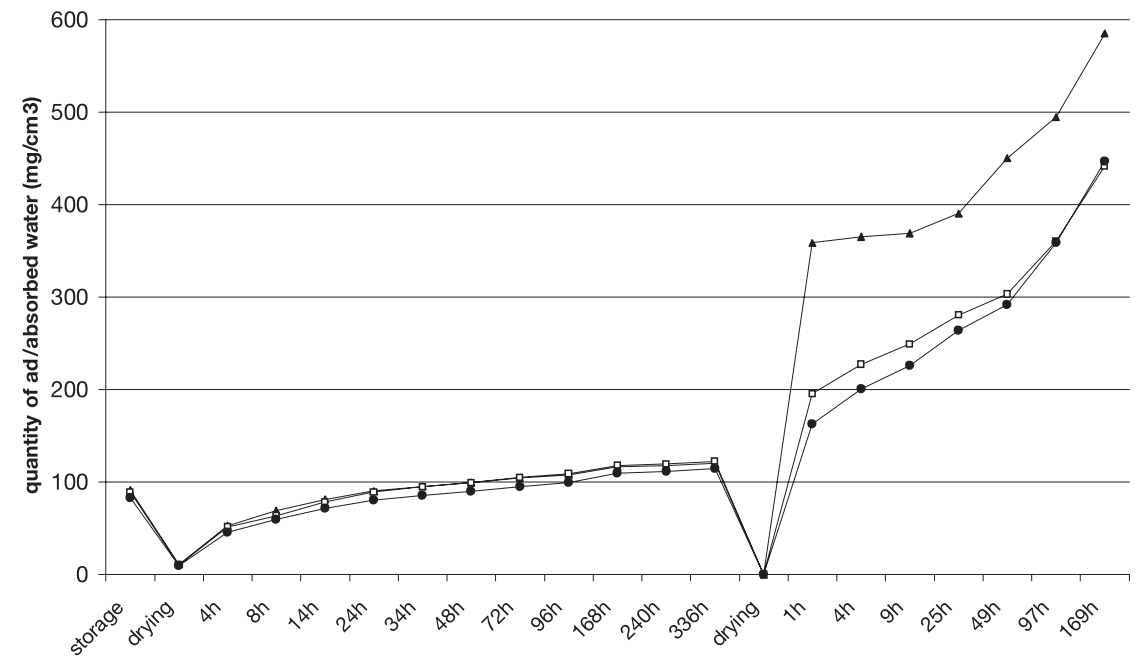

Figure 2. The average sorption of water into $5 \times 15 \times 30 \mathrm{~mm}$ sized wood blocks at high humidity (RH 100\%) (on the left) and when immersed in water (on the right) as a function of time at the temperature of about $25^{\circ} \mathrm{C}$. The blocks were dried at $60{ }^{\circ} \mathrm{C}$ for $48 \mathrm{~h}$ after storing, and at $103{ }^{\circ} \mathrm{C}$ for $24 \mathrm{~h}$ between the determinations. $\boldsymbol{\Delta}=$ sapwood, $\square=$ outer heartwood, $\bullet=$ inner heartwood.

Table II. Regression analysis with tree wise means $(n=16)$ with the mass loss as the response variable. The $R^{2}$ value shows the proportion of variation explained by the fitted model (response variable $=\beta_{0}+\beta_{1}$ independent variable $+\varepsilon$ ), and the $t$ statistics tests whether the parameter $\beta_{1}$, the sign of which only is presented, was significantly different from zero.

a. Sapwood

\begin{tabular}{lccc}
\hline Independent variable & $\mathrm{R}^{2}$ & $\begin{array}{c}\text { Sign } \\
\text { of } \beta_{1}\end{array}$ & $\begin{array}{c}p \text {-value } \\
\text { of } t \text { test }\end{array}$ \\
\hline Basic density & 0.03 & - & 0.526 \\
Total resin acids & 0.15 & + & 0.151 \\
Total phenolics by Folin-Ciocalteu & 0.00 & - & 0.811 \\
Moisture content at RH 100\% & 0.01 & - & 0.772 \\
Quantity of water after wetting & 0.13 & - & 0.171
\end{tabular}

b. Outer heartwood

\begin{tabular}{lccc}
\hline Independent variable & $\mathrm{R}^{2}$ & $\begin{array}{c}\text { Sign } \\
\text { of } \beta_{1}\end{array}$ & $\begin{array}{c}p \text {-value } \\
\text { of } t \text { test }\end{array}$ \\
\hline Basic density & 0.28 & + & 0.037 \\
Total resin acids & 0.01 & - & 0.724 \\
Total phenolics by Folin-Ciocalteu & 0.23 & - & 0.059 \\
PS & 0.14 & - & 0.159 \\
PSM & 0.25 & - & 0.048 \\
PS + PSM & 0.23 & - & 0.058 \\
Moisture content at RH 100\% & 0.21 & + & 0.077 \\
Quantity of water after wetting & 0.19 & + & 0.091
\end{tabular}

c. Inner heartwood

\begin{tabular}{lccc}
\hline Independent variable & $\mathrm{R}^{2}$ & $\begin{array}{c}\text { Sign } \\
\text { of } \beta_{1}\end{array}$ & $\begin{array}{c}p \text {-value } \\
\text { of } t \text { test }\end{array}$ \\
\hline Basic density & 0.00 & - & 0.826 \\
Total resin acids & 0.16 & - & 0.123 \\
Total phenolics by Folin-Ciocalteu & 0.27 & - & 0.040 \\
PS & 0.65 & - & $<0.001$ \\
PSM & 0.41 & - & 0.011 \\
PS + PSM & 0.51 & - & 0.003 \\
Moisture content at RH 100\% & 0.43 & + & 0.006 \\
Quantity of water after wetting & 0.17 & + & 0.111 \\
\hline
\end{tabular}

correlated. The concentration of resin acids showed no relationship with the variation in the moisture content or the quantity of water after wetting. The moisture content and the quantity of water after wetting did not correlate with each other. The relationships for the inner heartwood resembled those for the outer heartwood, even though the absolute amount of stilbenes was only half of that in the outer heartwood. Differently, the moisture content had nearly significant negative correlation with the concentration of total phenolics and the concentration of PS and resin acids. The correlation between the basic density of the wood and the absolute amount of water adsorbed $\left(\mathrm{mg} / \mathrm{cm}^{3}\right)$ by the wood at high humidity was 0.911 in the sapwood, 0.874 in the outer heartwood, and 0.722 in the inner heartwood (not shown in Tab. III).

Scatter plots were used to visualise the radial variation and the variation among the trees, as well as the relationships between the important wood characteristics (Figs. 3a-3e).

The concentration of stilbenes in the excluded sapwood samples was about 75 times that in typical sapwood. The average concentration of resin acids was $7.6 \mathrm{mg} / \mathrm{cm}^{3}$, and the concentration of total phenolics $1.12 \mathrm{mg} \mathrm{TAE} / \mathrm{cm}^{3}$ (expressed as tannic acid equivalents). The mass loss was $0.084 \mathrm{mg} / \mathrm{cm}^{3}$, the moisture content $27.9 \%$ and the quantity of water after wetting $0.564 \mathrm{~g} / \mathrm{cm}^{3}$. The reason for these outlying observations could have been mistakes in determining the boundary between the sapwood and heartwood. The concentration of resin acids in the excluded heartwood samples was about 8 times that in typical heartwood. The average concentration of stilbenes was $12.5 \mathrm{mg} / \mathrm{cm}^{3}$, and the concentration of total phenolics $8.01 \mathrm{mg}$ TAE $/ \mathrm{cm}^{3}$. The mass loss was $0.033 \mathrm{mg} / \mathrm{cm}^{3}$, moisture content $26.6 \%$ and the quantity of water after wetting $0.441 \mathrm{~g} / \mathrm{cm}^{3}$. The most important reason for these outlying observations was the vicinity of knots.

\section{DISCUSSION AND CONCLUSIONS}

The results of this study show that the most durable part of old Scots pine stems is the heartwood located next to the sapwood. The same kind of radial variation has been found in several other tree species ([30] and references therein). Erdtman and Rennerfelt [2] and Rennerfelt [22] carried out decay 

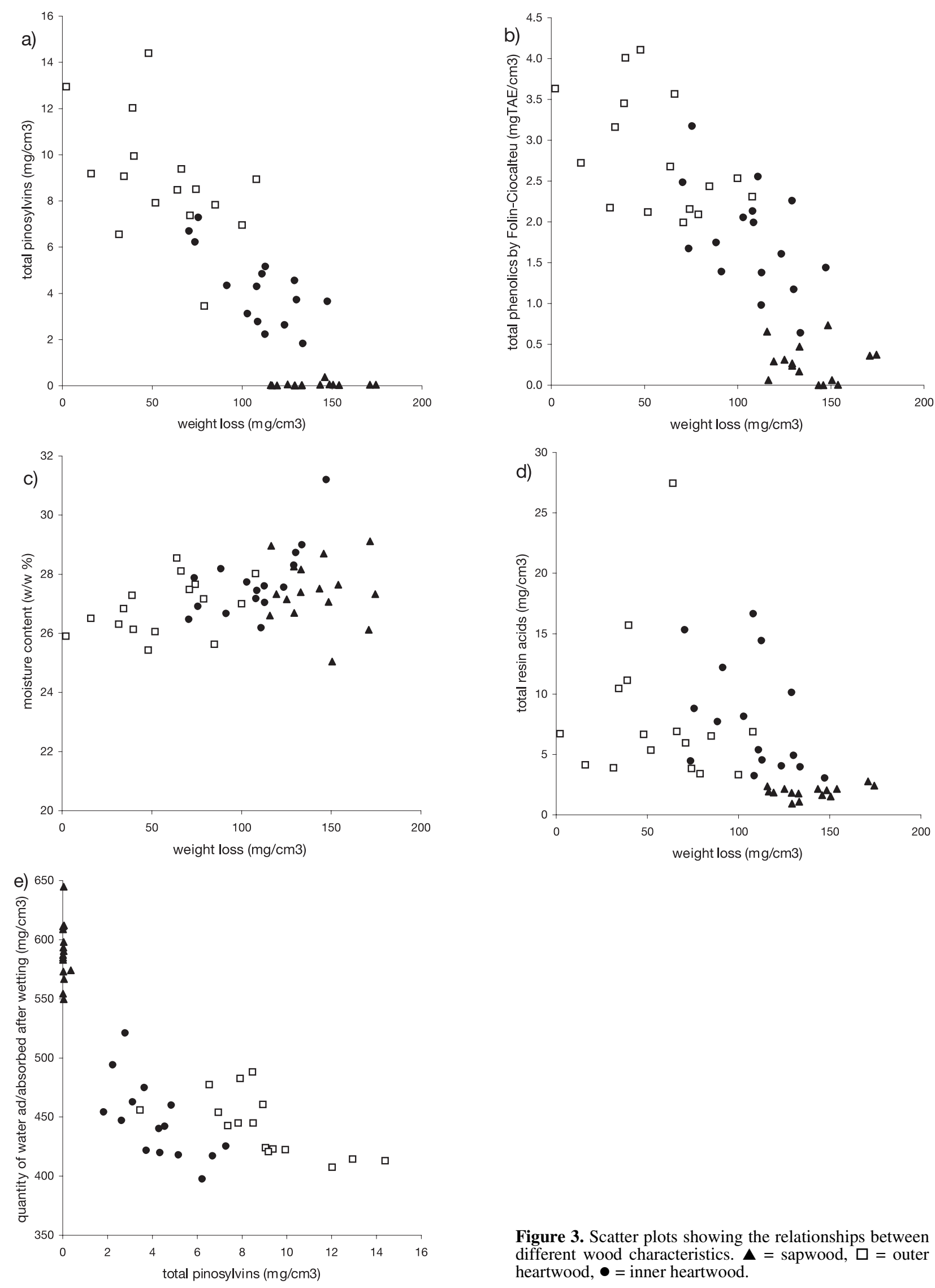

Figure 3. Scatter plots showing the relationships between different wood characteristics. $\boldsymbol{\Delta}=$ sapwood, $\square=$ outer heartwood, $\bullet=$ inner heartwood. 
Table III. Pearsons' correlation coefficients between Scots pine wood characteristics $(n=15-16)$. The $p$-values of the coefficients are given in italics.

\begin{tabular}{|c|c|c|c|c|c|c|c|}
\hline & Basic density & Resin acids & Total phenolics & Moisture content & & & \\
\hline Resin acids & $\begin{array}{c}0.194 \\
(0.487)\end{array}$ & & & & & & \\
\hline Total phenolics & $\begin{array}{c}0.144 \\
(0.609)\end{array}$ & $\begin{array}{c}0.171 \\
(0.542)\end{array}$ & & & & & \\
\hline Moisture content & $\begin{array}{c}0.194 \\
(0.471)\end{array}$ & $\begin{array}{l}-0.141 \\
(0.617)\end{array}$ & $\begin{array}{l}-0.235 \\
(0.400)\end{array}$ & & & & \\
\hline $\begin{array}{l}\text { Quantity of water } \\
\text { after wetting }\end{array}$ & $\begin{array}{c}0.179 \\
(0.508)\end{array}$ & $\begin{array}{l}-0.078 \\
(0.780)\end{array}$ & $\begin{array}{l}-0.320 \\
(0.245)\end{array}$ & $\begin{array}{l}-0.398 \\
(0.127)\end{array}$ & & & \\
\hline \multicolumn{8}{|l|}{ b. Outer heartwood } \\
\hline & Basic density & Resin acids & Total phenolics & PS & PSM & PS + PSM & Moisture content \\
\hline Resin acids & $\begin{array}{l}-0.185 \\
(0.493)\end{array}$ & & & & & & \\
\hline Total phenolics & $\begin{array}{c}0.003 \\
(0.992)\end{array}$ & $\begin{array}{c}0.310 \\
(0.243)\end{array}$ & & & & & \\
\hline PS & $\begin{array}{c}0.067 \\
(0.805)\end{array}$ & $\begin{array}{c}0.118 \\
(0.664)\end{array}$ & $\begin{array}{c}0.681 \\
(0.004)\end{array}$ & & & & \\
\hline PSM & $\begin{array}{c}0.160 \\
(0.553)\end{array}$ & $\begin{array}{c}0.236 \\
(0.378)\end{array}$ & $\begin{array}{c}0.778 \\
(0.000)\end{array}$ & $\begin{array}{c}0.683 \\
(0.004)\end{array}$ & & & \\
\hline $\mathrm{PS}+\mathrm{PSM}$ & $\begin{array}{c}0.131 \\
(0.628)\end{array}$ & $\begin{array}{c}0.202 \\
(0.453)\end{array}$ & $\begin{array}{c}0.802 \\
(0.000)\end{array}$ & & & & \\
\hline Moisture content & $\begin{array}{c}0.304 \\
(0.252)\end{array}$ & $\begin{array}{c}0.346 \\
(0.189)\end{array}$ & $\begin{array}{l}-0.297 \\
(0.263)\end{array}$ & $\begin{array}{l}-0.289 \\
(0.278)\end{array}$ & $\begin{array}{l}-0.275 \\
(0.303)\end{array}$ & $\begin{array}{l}-0.305 \\
(0.250)\end{array}$ & \\
\hline $\begin{array}{l}\text { Quantity of water } \\
\text { after wetting }\end{array}$ & $\begin{array}{l}-0.088 \\
(0.745)\end{array}$ & $\begin{array}{c}0.151 \\
(0.577)\end{array}$ & $\begin{array}{l}-0.739 \\
(0.001)\end{array}$ & $\begin{array}{l}-0.636 \\
(0.008)\end{array}$ & $\begin{array}{l}-0.583 \\
(0.018)\end{array}$ & $\begin{array}{l}-0.659 \\
(0.006)\end{array}$ & $\begin{array}{c}0.287 \\
(0.281)\end{array}$ \\
\hline \multicolumn{8}{|l|}{ c. Inner heartwood } \\
\hline & Basic density & Resin acids & Total phenolics & PS & PSM & PS + PSM & Moisture content \\
\hline Resin acids & $\begin{array}{l}0.003 \\
(0.990)\end{array}$ & & & & & & \\
\hline Total phenolics & $\begin{array}{l}-0.095 \\
(0.727)\end{array}$ & $\begin{array}{c}0.253 \\
(0.345)\end{array}$ & & & & & \\
\hline PS & $\begin{array}{l}-0.199 \\
(0.477)\end{array}$ & $\begin{array}{c}0.297 \\
(0.282)\end{array}$ & $\begin{array}{c}0.672 \\
(0.006)\end{array}$ & & & & \\
\hline PSM & $\begin{array}{l}-0.415 \\
(0.124)\end{array}$ & $\begin{array}{l}0.183 \\
(0.515)\end{array}$ & $\begin{array}{c}0.671 \\
(0.006)\end{array}$ & $\begin{array}{c}0.879 \\
(0.000)\end{array}$ & & & \\
\hline PS + PSM & $\begin{array}{l}-0.349 \\
(0.202)\end{array}$ & $\begin{array}{c}0.229 \\
(0.412)\end{array}$ & $\begin{array}{c}0.691 \\
(0.004)\end{array}$ & & & & \\
\hline Moisture content & $\begin{array}{c}0.104 \\
(0.702)\end{array}$ & $\begin{array}{l}-0.437 \\
(0.090)\end{array}$ & $\begin{array}{l}-0.482 \\
(0.059)\end{array}$ & $\begin{array}{l}-0.481 \\
(0.070)\end{array}$ & $\begin{array}{l}-0.348 \\
(0.204)\end{array}$ & $\begin{array}{c}-0.406 \\
(0.134)\end{array}$ & \\
\hline $\begin{array}{l}\text { Quantity of water } \\
\text { after wetting }\end{array}$ & $\begin{array}{c}0.099 \\
(0.715)\end{array}$ & $\begin{array}{l}-0.146 \\
(0.590)\end{array}$ & $\begin{array}{l}-0.126 \\
(0.641)\end{array}$ & $\begin{array}{l}-0.603 \\
(0.017)\end{array}$ & $\begin{array}{l}-0.683 \\
(0.005)\end{array}$ & $\begin{array}{l}-0.674 \\
(0.006)\end{array}$ & $\begin{array}{c}0.236 \\
(0.379)\end{array}$ \\
\hline
\end{tabular}

experiments on 1-7 Scots pine stems using several wood destroying fungi including C. puteana, and concluded that the mass loss in the periphery part of the heartwood was lower than that in the centre of the heartwood. The other marked difference between the outer and the inner heartwood found in the present study was in the concentration of pinosylvin (PS) and pinosylvin monomethyl ether (PSM). This has earlier been reported on the basis of colorimetric analyses of total pinosylvins $[2,3,22]$.
The variation in mass loss, caused by the $C$. puteana brownrot fungus during the relatively short incubation period, was large within the radial sections. The variation within the most durable section, i.e. the outer heartwood, was the largest. However, the variation could not be explained satisfactorily by the other wood characteristics. Only the concentration of PSM had a significant effect at the 0.05 risk level. In the inner heartwood, the role of the stilbenes PS and PSM as decay inhibiting agents was significant at a low risk level, but the 
proportion of unexplained variation remained high. Furthermore, no independent variable explained the mass loss in the sapwood variation. Together this indicates that either the variation in the in vitro decay test had a large random component or that the activity of the fungus is dependent on unknown factors. If incubation with the outer heartwood had been longer and the average mass loss larger, more significant factors might have appeared.

The concentration of the stilbenes PS and PSM appeared to be the most important single factor determining the natural durability of Scots pine heartwood. This conclusion was supported by the difference in the average mass loss and in the average concentration of heartwood phenolics between the sapwood and the outer and inner heartwood, as well as by the dependence between the mass loss and the PS + PSM concentration, especially within the inner heartwood. The same conclusion was also made by Rennerfelt [22]. However, as shown in Figure IIIa, the decay rates of samples with very different PS + PSM levels can overlap. This supports the suggestion that the activity of the fungus is not regulated only by stilbenes $[14,26]$. The results of this study do not provide very much information about the mechanism through which PS and PSM slow down the degradation processes.

The role of resin acids in the decay resistance of natural wood substrate seemed to be minor compared to that of stilbenes (Figs. 3a, 3b and 3d). The concentration of resin acids was approximately the same in the inner and outer heartwood, and thus could not have contributed to the significant variation in the mass loss observed between the inner and outer heartwood. The variation in the concentration of resin acids among the samples was large but, according to the regression analysis, the variation within the normal range had a weak effect on the mass loss, and in this case only in the inner heartwood. The extremely resinous "outlying" samples were relatively durable, but the concentration of phenolics in these samples was also high. This is in accordance with the comparison study of Harju et al. [12], in which the resin acid concentration of decay resistant and susceptible juvenile Scots pine heartwood was significant in one stand $(p=0.004)$, and nearly significant in another $(p=0.072)$. In the significant case the average concentration of resin acids was double in the susceptible heartwood and four-fold in the resistant heartwood compared to the heartwood material of the present study, taken from the upper part of the stems.

The traditional use of pine tar and pitch for ship caulking, i.e. as "naval stores" (see e.g. $[15,19]$ ), may be the reason for the speculation that resin acids in situ would make the wood hydrophobic. This hypothesis was not supported by the present study, in which the relationship between the total resin acid concentration and the water sorption capacity was analysed in natural wood substrate. Within the radial sections, there was no significant correlation between the resin acid concentration and the moisture content in humid air or the quantity of water after wetting. Even among the eight-fold resinous, "outlier" heartwood samples, the moisture content and the quantity of water after wetting were at almost the same level as in the typical heartwood.

The moisture content was the characteristic that showed the least variation both between and within the radial sections.
However, this small degree of variation explained to some extent the large variation in the heartwood mass loss. The uptake of water at the start of the malt agar plate decay test took place via adsorption. In conditions where the moisture content of the wood surface is near to the lower limit required by the fungus to be active, even small differences in the adsorption rate may cause a delay in decay initiation. The results showed no significant relationship between the moisture content (adsorption) and the quantity of water after wetting (adsorption + absorption), which suggests that adsorption and absorption, both of which depict the interaction between the wood and water, actually reflect completely different wood properties.

The quantity of water after wetting and the concentration of stilbenes showed a significant negative correlation within both the outer and inner heartwood even though there was no difference in the average quantity of water between the outer and the inner heartwood (Fig. 3e). There are a few earlier reports on the ability of phenolics to interfere with the penetration of water inside Scots pine wood [1, 26, 28]. The reason for this relationship does not necessarily have to be related to the chemical nature of phenolic compounds, but it could also be a specific feature in the structure of the wood that is correlated with the concentration of phenolics and the absorption of water. The interesting finding that the quantity of water after wetting to some extent also explained the variation in heartwood mass loss, even though there was no external supply of free water in the decay test, may be a reflection of the correlation between the absorption of water and the amount of stilbenes.

The concentration of phenolics was investigated using two different methods: the non-specific colorimetric Folin-Ciocalteu method, and the specific liquid chromatography analysis (HPLC). In heartwood, where the concentration of phenolics was high, the results of these methods were in good agreement. The Folin-Ciocalteu method also satisfactorily explained the variation in mass loss, which suggests that this simple method could be useful in the screening of durable Scots pine heartwood (Fig. 3b).

Acknowledgements: This study has been supported by the Academy of Finland. The authors are also grateful to a number of persons for their assistance during the work. The sample trees were felled and the disks cut by Ari Haapasaari and Pentti Konttinen under the supervision of Hannu Heinonen. The sample disks were handled by Heikki Kinnunen and Sari Lignell. The mycological analysis was carried out by Katriina Lipponen, Anna-Maija Hallaksela and Kerttu Rainio. The sample blocks were prepared by Auvo Silvennoinen and Heikki Kinnunen, and the milling was carried out by Eija Matikainen and Auvo Silvennoinen. The decay test was performed by Liisa Seppänen. Hannele Makkonen, Seija Vatanen and Eija Matikainen performed the determinations with the wood blocks and water. John Derome revised the language of the manuscript.

\section{REFERENCES}

[1] Celimene C.C., Micales J.A., Ferge L., Young R.A., Efficacy of pinosylvins against white-rot and brown-rot fungi, Holzforschung 53 (1999) 491-497.

[2] Erdtman V.H., Rennerfelt E., Der Gehalt des Kiefernkernholzes an Pinosylvin-Phenolen. Ihre quantitative Bestimmung und ihre hemmende Wirkung gegen Angriff verschiedener Fäulpilze, Svensk Papperstidning 47 (1944) 45-56. 
[3] Erdtman H., Frank A., Lindstedt G., Constituents of pine heartwood XXVII. The content of pinosylvin phenols in Swedish pines, Svensk Papperstidning 8 (1951) 275-279.

[4] Ericsson T., Fries A., High heritability for heartwood in north Swedish Scots pine, Theor. Appl. Genet. 98 (1999) 732-735.

[5] Ericsson T., Fries A., Gref R., Genetic correlations of heartwood extractives in Pinus sylvestris progeny test, For. Genet. 8 (2001) 73-80.

[6] European standard, EN 350-2, Durability of wood and wood-based products - Natural durability of solid wood - Part 2: Guide to Natural durability and treatability of selected wood species of importance in Europe. European Committee for Standardization, Brussels, 1994.

[7] Fries A., Ericsson T., Genetic parameters in diallel-crossed Scots pine favour heartwood formation breeding objectives, Can. J. For. Res. 28 (1998) 937-941.

[8] Fries A., Ericsson T., Gref R., High heritability of wood extractives in Pinus sylvestris progeny test, Can. J. For. Res. 30 (2000) 1707-1713.

[9] Gref R., Ericsson A., Wound-induced changes of resin acid concentrations in living bark of Scots pine seedlings, Can. J. For. Res. 15 (1985) 92-96.

[10] Griffin D.M., Water potential and wood-decay fungi, Ann. Rev. Phytopathol. 15 (1977) 319-329.

[11] Harju A.M., Venäläinen M., Genetic parameters regarding the resistance of Pinus sylvestris heartwood to decay caused by Coniophora puteana, Scand. J. For. Res. 17 (2002) 199-205.

[12] Harju A.M., Kainulainen P., Venäläinen M., Tiitta M., Viitanen H., Differences in resin acid concentration between brown-rot resistant and susceptible Scots pine heartwood, Holzforschung 56 (2002) 479-486.

[13] Harju A.M., Venäläinen M., Beuker E., Velling P., Viitanen H., Genetic variation in the decay resistance of Scots pine wood against brown rot fungus, Can. J. For. Res. 31 (2001) 1244-1249.

[14] Hart J.H., Shrimpton D.M., Role of stilbenes in resistance of wood to decay, Phytopathology 69 (1979) 1138-1143.

[15] Hillis W.E., Heartwood and tree exudates, Springer-Verlag, Berlin Heidelberg, 1987.

[16] Julkunen-Tiitto R., Phenolic constituents in the leaves of northern willows: Methods for the analysis of certain phenolics, J. Agric. Food Chem. 33 (1985) 213-217.

[17] Lieutier F., Sauvard D., Brignolas F., Picron V., Yart A., Bastien C., Jay-Allemand C., Changes in phenolic metabolites phloem induced by Ophiostoma brunneo-ciliatum, a bark-beetle-associated fungus, Eur. J. For. Path. 26 (1996) 145-158.
[18] Manninen A.-M., Tarhanen S., Vuorinen M., Kainulainen P., Comparing the variation of needle and wood terpenoids in Scots pine provenances, J. Chem. Ecol. 28 (2002) 211-228.

[19] Obst J.R., Special (secondary) metabolites from wood, in: Bruce A., Palfreyman J.W. (Eds.), Forest products biotechnology, Taylor \& Francis Ltd, Padstow, UK, 1998, pp. 151-165.

[20] Paajanen L., Viitanen H., Decay fungi in Finnish houses on the basis of inspected samples from 1978 to 1988, The International Research Group on Wood Preservation, IRG Doc. No: IRG/WP/ 1401, 1989, 4 p.

[21] Rayner A.D.M., Boddy L., Fungal decomposition of wood. Its biology and ecology, John Wiley and Sons, Chichester, UK, 1988.

[22] Rennerfelt E., Några undersökningar över olika rötsvampars förmåga att angripa splint- och kärnved hos tall. Summary: Some investigations over the capacity of some decay fungi to attack sapwood and heartwood of Scots pine, Medd. Statens Skogsförsöksanstalt 36 (1947) 1-24.

[23] Scheffer T.C., Cowling E.B., Natural resistance of wood to microbial deterioration, Ann. Rev. Phytopathol. 4 (1966) 147-170.

[24] Turtola S., Manninen A.-M., Holopainen J.K., Levula T., Raitio H., Kainulainen P., Secondary metabolite concentrations and terpene emissions of Scots pine xylem after long-term forest fertilization, J. Env. Qual. 31 (2002) 1694-1701.

[25] Venäläinen M., Harju A., Nikkanen T., Paajanen L., Velling P., Viitanen H., Genetic variation in the decay resistance of Siberian larch (Larix sibirica Ledeb.) wood, Holzforschung 55 (2001) 1-6.

[26] Venäläinen M., Harju A., Saranpää P., Kainulainen P., Tiitta M., Velling P., The concentration of phenolics in brown-rot decay resistant and susceptible Scots pine heartwood, Wood Sci. Technol. (in press).

[27] Viitanen H., Paajanen L., Nikkanen T., Velling P., Decay resistance of Siberian larch wood against brown rot fungi, Part 2, The effect of genetic variation, The International Research Group on Wood Preservation, Stockholm, IRG Doc. No: IRG/WP 98-10287, 1998.

[28] Vologdin A., Razumova A.F., Charuk E.V., Die Bedeutung der Extraktstoffe für die Permeabilität von Kiefern- und Fichtenholz, Holztechnologie 20 (2) (1979) 67-69.

[29] Walker J.C.F., Primary Wood Processing: pinciples and practice. Chapman, Hall, London, 1993.

[30] Zabel R.A., Morrell J.J., Wood Microbiology: Decay and its Prevention, Academic Press Inc., California, 1992. 